\title{
General Election Law Position In The Enforcement Of Criminal Law
}

\section{Eko Nuryanto*) and Gunarto**)}

*) Student of Masters (S2) of Law Faculty of Law Unissula and Attorney General's Office of the Republic of Indonesia, Merauke District, email: echokejarimkw@gmail.com

${ }^{* *}$ Faculty of Law Universitas Islam Sultan Agung

\begin{abstract}
The aim in this study, to find out and analyze the mechanism for law enforcement of election criminal acts based on the General Election Law. In this research, the writer used sociological juridical method with the research specification in the form of descriptive analysis. The data used for this research are primary and secondary data. Based on the results of research that concludes, namely the mechanisms in the election criminal justice process based on Act No. 7 of 2017 concerning Elections through investigations in Article 479, investigations in Article 480 paragraph 1, prosecution in Article 480 paragraph 4, and court in Article 481 paragraph 1 The District Court exercises the authority to examine, adjudicate, and decide on cases where the process is carried out in a special court which still refers to the stages of the general criminal justice process in the Criminal Procedure Code.

Keywords: Law, General Elections, Criminal Law Enforcement.
\end{abstract}

\section{Introduction}

The Preamble to the 1945 Constitution of the Republic of Indonesia states that Indonesia is a country based on law ${ }^{1}$, then every criminal act that occurs should be processed through legal channels, so law is seen as the only means for the settlement of a criminal act. ${ }^{2}$ Criminal acts are actions that are not only defined by the Criminal Code as crimes or criminal acts. ${ }^{3}$ In addition, according to Moeljatno, a criminal act is an act that is prohibited by a prohibition law which is accompanied by a threat (sanction) in the form of a certain crime. ${ }^{4}$

In addition to a constitutional state, Indonesia is also a democratic country where each process of electing representatives of the people where the process includes the head of state, regional heads and members of the legislature ${ }^{5}$ This is intended as an effort by Indonesia as a rule of law to protect its people from freedom of speech in the context of general elections ${ }^{6}$ this is regulated in Article 1

\footnotetext{
${ }^{1}$ Tafta Aji Prihandono and Sri Kusriyah, Awareness on Constitutional Rights of Citizens and Form of Protection of Constitutional Rights of Citizens in Indonesia, Jurnal Daulat Hukum, Vol.1 No.4, December 2018, url: http://jurnal.unissula.ac.id/index.php/RH/article/view/4145/2895

${ }_{2}^{2}$ Jimly Asshiddiqie, 2005, Konstitusi dan Konstitusionalisme Indonesia, Penerbit Konstitusi Press, Jakarta, p. 68

${ }^{3}$ S.R. Sianturi, 2002, Asas-asas Hukum Pidana di Indonesia dan Penerapannya, Ed.3, Jakarta:Storia Grafika, p. 204

${ }^{4}$ C.S.T. Kansil and Christine S.T. Kansil, 2004, Pokok-pokok Hukum Pidana, Jakarta, Pradnya Paramita, p. 54.

${ }^{5}$ Rosalia Widhiastuti Sri Lestari, Analisa Melek Politik Warga pada Pemilu Legislatif Tahun 2014, Jurnal Aristo, Vol.4 No.1, 2016

${ }^{6}$ Achmad Sulchan, 2016, Perkara Pidana Pemilihan Umum Yang Bernilai Keadilan, Publising, Semarang, p. 10
} 
number (1) of Act No. 7 of 2017 concerning General Elections, that General Elections, hereinafter referred to as Elections, are a means of people's sovereignty to elect members of the People's Representative Council, members of the Regional Representative Council, the President and Vice President, and for to elect members of the Regional People's Representative Council, which is carried out directly, publicly, freely, secretly, honestly and fairly in the Unitary State of the Republic of Indonesia based on Pancasila and the 1945 Constitution of the Republic of Indonesia.

To ensure free and fair elections, which are very important for a democratic country, protection is needed for voters, for every party participating in the election and for the general public from all fears, intimidation, bribery, fraud, and various other fraudulent practices, which will affect purity. general election results. ${ }^{7}$ If elections are won through malpractices, it is difficult to say that the elected leaders or legitarians in parliament are representatives of the people. ${ }^{8}$ Election criminal acts, namely all criminal acts related to the administration of elections that are regulated in the Election Law. Criminal acts that occur during the election period, but which are not regulated in the Election Law are not classified as election crimes. The subjects of election crimes are human beings as individuals. ${ }^{9}$

The problem that arises is that there are various kinds of criminal acts committed that have spread in various regions in the Election of Candidates for Leadership and until now there have been difficulties in obtaining written evidence to process them legally. Whereas the law in Indonesia always demands written evidence to be able to bring someone to court accused of having committed a criminal act in a general election. The election criminal acts are a type of criminal act regulated in the Criminal Code, although they are further regulated in various Election Laws, therefore election crimes are considered special crimes. Elections are held once every five years and election criminal acts occur in the Election period every five years. Even though it is only held once every five years, an election must not be flawed and tarnished, and anyone who tarnishes or tries to tarnish an election is very appropriate if it is dealt with firmly. ${ }^{10}$

At this time the Election has been tarnished (there are many cheatings in the implementation of the Election, although very few cases have been revealed as election crimes), for example, some people vote twice, use other people's voting rights, money politics, election administrators who are not honest in their calculations votes, engineering the Final Voters List (DPT), and so on. This is a description of cases of electoral fraud, hereinafter referred to as election crime. ${ }^{11}$ Political costs in Indonesia are very expensive. As a result, many highranking political parties have tried to play with the state budget, which in the end

\footnotetext{
${ }^{7}$ Sri Herlina, and Umar Ma'ruf, Law Enforcement Against Elections Crime During Electoral Campaign 2019 (Case Study In Bawaslu of Banjarmasin City), Jurnal Daulat Hukum, Vol.2 No.3, September 2019, url: http://jurnal.unissula.ac.id/index.php/RH/article/view/5656/3381

8 Topo Santoso, 2006, Tindak Pidana Pemilu, Sinar Grafika, Jakarta, p. V

${ }^{9}$ Ibid, p. V

${ }^{10}$ Dedi Mul yadi, 2012, Kebijakan Legislasi Tentang Sanksi Pidana Pemilu Legislatif di Indonesia Dalam Perspekrif Demokrasi, Gramata Publising, p. 8

${ }^{11}$ Ibid, p. 8
} 
drags them into corruption. Representatives from political parties admit that political party finances have not been managed professionally and transparently. Many political party activities cost a lot of money, but the source of the funding is not clear. The importance of enforcing criminal law on the implementation of elections as a last resort (Ultimum Remidium) in saving the objectives of the General Election. The level of competition and contestation between executive candidates and legislative candidates is very large. This is due to the crystallization of political interests between the participating candidates and their supporting parties.

\section{Research Methods}

To conduct a study in this study the author uses the sociological juridical method. In the sociological juridical approach, law as law in action is described as an empirical social phenomenon. Thus, law is not only given a meaning as a chain of values, official decisions, fabric of rules and norms, written positive law, but can also be given meaning as a teaching system about reality. The specification in this research is descriptive analysis. The data used for this research are primary and secondary data. Primary data is data obtained directly from the field or from the first source and has not been processed by other parties. Then secondary data is data obtained from library research. The data used were collected through the stages of field observations, interviews,

\section{Results And Discussion}

\subsection{Election Crime Enforcement Mechanism Based on the General Election Law}

As part of the criminal law regime, the election criminal justice mechanism also follows the criminal justice system in general. In the criminal justice system, there is an integrated framework of a judicial system network that utilizes criminal law (material criminal law, formal criminal law and criminal implementation law) in an integrated manner. ${ }^{12}$ Within this framework, all elements of the law enforcement sub-system consisting of the police, prosecutors, courts and prisons are involved in a network that is interrelated with one another.

In the results of the author's interview with the judge at the Merauke District Court as the location of the research, Orpha Martinha explained that regarding law enforcement on election crimes that:

"It is pleased that there are voters whose names of violations must be acted upon, then the names of elections can only be once, if more than that it will be delegated to the police and the court. In Act No. 10 of 2016, the rules regarding Regional Head Elections are clear. In making a decision, the judge considers several things, the first is his actions, the decision already has legal considerations. Secondly, the prosecution process and the third is the trial process where there must be evidence that provides information and evidence that makes the

\footnotetext{
12 Khairul Fahmi, Sistem Penanganan Tindak Pidana Pemilu, FH Universitas Andalas, Jurnal Konstitusi, Vol.12 No.2, June 2015, p. 275
} 
perpetrator easier to carry out the criminal act process so that there is such a thing as judicial power to decide in court in accordance with justice. One of the preventive processes is the existence of a decision that is regulated in the 197 KUHAP. The name of a criminal decision is one of the preventive steps apart from providing legal counseling to the public. The handling process is already the last resort in an integrated criminal justice system, then the public must be smarter in conducting elections and must be wiser in the process of organizing the election."13

Furthermore, the mechanisms in the election criminal justice process are based on Act No. 7 of 2017 concerning Election in the form of:

a. In conducting an investigation, the investigator finds sufficient preliminary evidence of an alleged election criminal act, the results of the investigation accompanied by the case file are submitted to the investigator no later than $1 \mathrm{x}$ 24 (one twenty four) hours (Article 479);

b. Investigators of the State Police of the Republic of Indonesia submit the results of their investigations accompanied by case files to the public prosecutor no later than 14 (fourteen) days after receipt of the report and can be carried out in the absence of the suspect (Article 480 paragraph 1);

c. In the event that the results of the investigation are incomplete, within 3 (three) days the public prosecutor returns the case file to the Investigator of the State Police of the Republic of Indonesia accompanied by instructions on what to do to be completed (Article 480 paragraph 2);

d. (2) The investigators of the State Police of the Republic of Indonesia within 3 (three) days from the date of receipt of the files as intended in paragraph (2) must have submitted the case files back to the public prosecutor (Article 480 paragraph 3);

e. The public prosecutor delegates the case files as referred to in paragraph (1) and paragraph (3) to the District Court no later than 5 (five) days after receiving the case file and can be carried out in the absence of the suspect (Article 480 paragraph 4);

f. The District Court exercises the authority to examine, hear, and decide cases (Article 481 paragraph 1). ${ }^{14}$

In the research the authors produced a document in the form of an example of the decision of the Merauke District Court on an election criminal case that occurred in the research area in Merauke Regency as a final mechanism in law enforcement for election criminal acts in the form of a post-conflict local election in Merauke Regency which contained the following decisions:

The Merauke District Court, which tried criminal cases using ordinary examination procedures in the first instance, gave the following decisions in the defendant's case:

Full name $\quad$ : FREDERIKUS GEBZE, SE, M. Si . ;

Place of birth : Jayapura;

Age / Date of Birth : 47 Years / 25 November 1971;

Gender : Male;

${ }^{13}$ Interview with Orpha Martinha, SH, a Judge at the Merauke District Court on 10 June 2020

14 Interview with Orpha Martinha, SH, a Judge at the Merauke District Court on 10 June 2020 


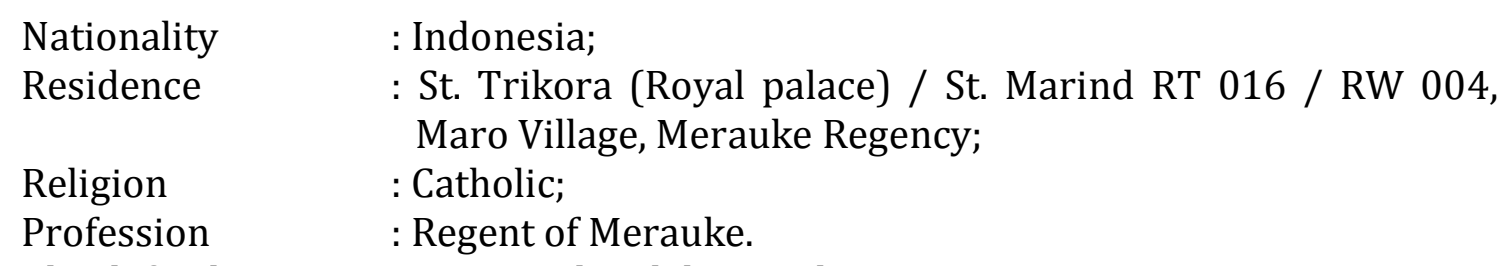

The defendant was not arrested and detained;

The defendant was accompanied by the Legal Counsel DOMINGGUS FRANS, SH, MH and PASKALIS LETSOIN, SH, MH, having his office address at St. Ermasu Number 36 Village of Mandala, Merauke District, Merauke Regency, based on a Special Power of Attorney dated June 13, 2019;

The District Court;

After reading:

- Determination of the Chairman of the District Court Number 97 / Pid.Sus / 2019 / PN.Mrk dated 11 June 2019 concerning the appointment of the Panel of Judges;

- Determination of the Panel of Judges Number 97 / Pid.Sus / 2019 / PN.Mrk dated 11 June 2019 concerning the determination of the day of the trial;

- Case files and other documents concerned;

Noting, Article 547 of Act No. 7 of 2017 concerning General Elections, and Act No. 8 of 1981 concerning Criminal Procedure Law, as well as other relevant laws and regulations;

\section{JUDGE}

1. Declare that the Defendant FREDERIKUS GEBZE, SE, M.Si, as mentioned above, was legally and convincingly proven guilty of committing a criminal act of "Committing an act that harmed an election contestant during the campaign period" as in the Single Indictment;

2. Imposing the punishment to the Defendant is therefore subject to imprisonment of 4 (four) months and a fine of IDR 10,000,000.00 (ten million rupiah) provided that if the fine is not paid, it is replaced by imprisonment for 15 (fifteen) days;

3. Determine that said punishment does not need to be served unless there is a judge's decision which determines otherwise because the convict has committed a criminal offense before the probation period for the last 8 (eight) months;

4. Determine evidence in the form of:

- 2 (two) green and black Caviar brand flash drives;

Returned to Witness Steven Abraham;

- 1 (one) 32GB V-Gen SDHC memory card;

Returned to Witness Marthen Haryanto Mahuze known as Anto;

5. To charge the Defendant to pay a court fee of IDR 5,000.00 (five thousand rupiah). ${ }^{15}$

In the criminal law of elections, this work system is inseparable from the general criminal justice system. It's just that, there are a number of special characters contained in the election criminal law. First, in terms of the material law

${ }^{15}$ Decision Number 97 / Pid.Sus / 2019 / PN.Mrk 
used, election criminal acts are specifically regulated in the Election Law and the Regional Election Law. A number of election crimes have even previously been determined as general crimes, such as committing violence or threats of violence (Article 293 of the Election Law), falsifying documents (298 of the Election Law), committing vandalism (Article 311 of the Election Law). However, the regulation of various criminal acts in the Election Law is related to the implementation of elections. $^{16}$

Secondly, from a formal legal aspect, election criminal law is also subject to the applicable provisions in the Criminal Procedure Code (KUHAP). Where, in examining, adjudicating, and deciding cases of criminal elections, the district court uses the KUHAP, unless otherwise stipulated in the Election Law. One of its specificities is the very limited time for investigation, prosecution and examination by the court. The time limitation in examining and adjudicating election crimes is actually intended so that the handling of election crimes can provide legal certainty for the stages of election administration. Apart from that, the specificity of election crimes is also seen in the limitations of legal remedies for people who are found guilty of committing election crimes. Where, an appeal can only be made against a court decision and the decision of the appellate court (High Court) has a final character and remembers and no other remedy can be made. Thus, cassation as an ordinary remedy is not available in the examination of election crimes. ${ }^{17}$

Third, election criminal law enforcement does not only involve law enforcement officials in the ordinary criminal justice system, but also involves election management institutions, in this case Bawaslu and its staff. Investigation of alleged election crimes must first be with a report / recommendation from the Provincial Bawaslu ${ }^{18}$ and Panwaslu of Regency / City. ${ }^{19}$ In this mechanism, allegations of election violations must first go through a study by Bawaslu and its ranks. Where, if the results of the election supervisor's study conclude that there are allegations of election criminal acts, the results of the study along with the recommendations of the election supervisors are forwarded to police investigators. Because it involves a number of institutions in the handling of election crimes, for the purpose of equalizing the understanding and patterns of handling election crimes by Bawaslu, the Police and the Attorney General's Office, an integrated law enforcement center (Sentra Gakumdu) has been established. Where, this institution is positioned as a place to equate views between institutions involved in handling election crimes. ${ }^{20}$

Fourth, examination of criminal cases is handled by a special panel established in district and high courts. Where, special judges in election criminal cases must have certain conditions and qualifications whose appointment is determined based on the Second Decree of the Supreme Court of the Republic of Indonesia. ${ }^{21}$

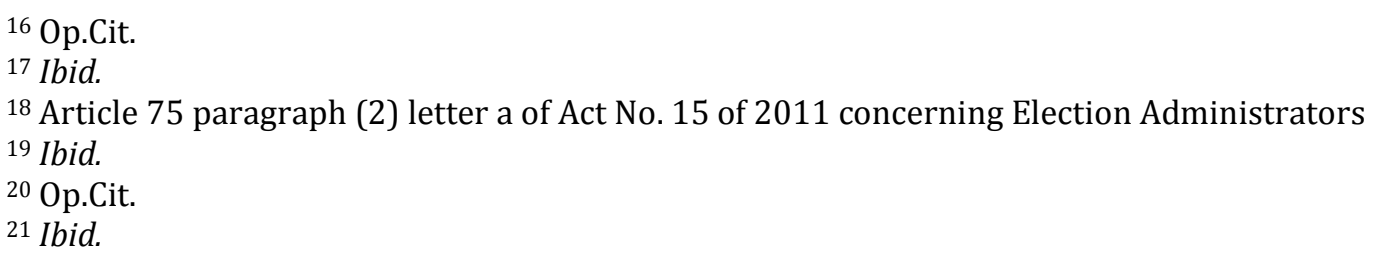


The complexity of the legal products created for the holding of elections in Indonesia as a manifestation of legal certainty in the process of general election for leader candidates who will represent the voice of the people in all aspects as a stake in the welfare and prosperity of the people in the future. ${ }^{22}$ Because basically, the legal objectives that are closer to realistic are legal certainty and legal benefits. Positivism places more emphasis on legal certainty, whereas functionalists prioritize legal benefits, and if it can be argued that "summon ius, summa injuria, summa lex, summa crux" which means harsh laws can hurt, unless justice can help it, thus although justice is not the sole objective of law, the substantive goal of law is justice. ${ }^{23}$

\section{Closing}

The mechanism in the election criminal justice process which is based on Act No. 7 of 2017 concerning Elections in the form of Investigators in conducting investigations finds sufficient preliminary evidence of alleged Election criminal acts, the results of the investigation along with the case files are submitted to the investigator no later than 1 x 24 (one time twenty four) hours (Article 479), State Police Investigators of the Republic of Indonesia submit the results of their investigation along with the case files to the public prosecutor no later than 14 (fourteen) days after the report is received and can be carried out in the absence of the suspect (Article 480 paragraph 1). incomplete investigation, within 3 (three) days the public prosecutor returns the case file to the Investigator of the State Police of the Republic of Indonesia along with instructions on what to do to be completed (Article 480 paragraph 2), the Investigator of the State Police of the Republic of Indonesia within 3 (three) days from the date of receipt of the files as referred to in paragraph (2) must have submitted the case files back to the public prosecutor (Article 480 paragraph 3), the public prosecutor shall submit the case files as referred to in paragraph (1) and paragraph (3) to the District Court at the latest. 5 (five) days after receiving the case file and it can be carried out in the absence of the suspect (Article 480 paragraph 4), the District Court shall exercise the authority to examine, hear and decide the case (Article 481 paragraph 1).(2) The investigators of the State Police of the Republic of Indonesia within 3 (three) days from the date of receipt of the files as referred to in paragraph (2) must have submitted the case files back to the public prosecutor (Article 480 paragraph 3), the public prosecutors shall hand over the case files as referred to in paragraph (1) and paragraph (3) to the District Court no later than 5 (five) days after receiving the case file and can be carried out in the absence of the suspect (Article 480 paragraph 4), the District Court exercises the authority to examine, try and decide cases (Article 481 paragraph 1).(2) The investigators of the State Police of the Republic of Indonesia within 3 (three) days from the date of receipt of the files as referred to in paragraph (2) must have submitted the case files back to the public prosecutor (Article 480 paragraph 3), the public prosecutors shall hand over the

${ }^{22}$ Ika Yuana Darmayanti, Law Politics Of Legislative Election, Jurnal Daulat Hukum, Vol.2 No.2, June 2019, url: http://jurnal.unissula.ac.id/index.php/RH/article/view/5414/3341

${ }^{23}$ Dosminikus Rato, 2010, Filasafat Hukum Mencari dan Memahami Hukum, PT Presindo, Yogyakarta, p. 59 
case files as referred to in paragraph (1) and paragraph (3) to the District Court no later than 5 (five) days after receiving the case file and can be carried out in the absence of the suspect (Article 480 paragraph 4), the District Court exercises the authority to examine, try and decide cases (Article 481 paragraph 1).The public prosecutor delegates the case files as referred to in paragraph (1) and paragraph (3) to the District Court no later than 5 (five) days after receiving the case file and can be carried out in the absence of the suspect (Article 480 paragraph 4), the District Court exercises the authority to examine, try and decide cases (Article 481 paragraph 1).The public prosecutor delegates the case files as referred to in paragraph (1) and paragraph (3) to the District Court no later than 5 (five) days after receiving the case file and can be carried out in the absence of the suspect (Article 480 paragraph 4), the District Court exercises the authority to examine , try and decide cases (Article 481 paragraph 1).

The system for handling election criminal acts still needs improvement so that it can be implemented properly and effectively to become one of the instruments for realizing honest and fair elections. Improvement of the handling system includes improving regulations, strengthening the capacity and professionalism of election law enforcers; and increasing legal awareness of all election stakeholders. Without doing that, the system for handling election crimes will always be in place and will not be effective in sustaining the realization of an honest and fair election. It is important to strengthen the role of Bawaslu not only in conducting the supervisory process. Also carry out the process of investigation to prosecution. However, due to the nature of elections which are once in five years, Bawaslu can appoint a temporary investigator and public prosecutor. Investigators and public prosecutors can be recruited from the police and prosecutors. Or submit election criminal offenses to the police on the condition that there is an increase in the capacity of the police in electoral matters and this is carried out in special units.

\section{References}

\section{Journals:}

[1] Ika Yuana Darmayanti, Law Politics Of Legislative Election, Jurnal Daulat Hukum, Vol.2 No.2, June 2019, url: http://jurnal.unissula.ac.id/index.php/RH/article/view/5414/3341

[2] Khairul Fahmi, Sistem Penanganan Tindak Pidana Pemilu, FH Universitas Andalas, Jurnal Konstitusi, Vol.12 No.2, June 2015, p. 275

[3] Rosalia Widhiastuti Sri Lestari, Analisa Melek Politik Warga pada Pemilu Legislatif Tahun 2014, Jurnal Aristo, Vol.4 No.1, 2016

[4] Sri Herlina, and Umar Ma'ruf, Law Enforcement Against Elections Crime During Electoral Campaign 2019 (Case Study In Bawaslu of Banjarmasin City), Jurnal Daulat Hukum, Vol.2 No.3, September 2019, url: http://jurnal.unissula.ac.id/index.php/RH/article/view/5656/3381

[5] Tafta Aji Prihandono and Sri Kusriyah, Awareness on Constitutional Rights of Citizens and Form of Protection of Constitutional Rights of Citizens in Indonesia, Jurnal Daulat Hukum, Vol.1 No.4, December 2018, url: http://jurnal.unissula.ac.id/index.php/RH/article/view/4145/2895 
Books:

[1] Achmad Sulchan, 2016, Perkara Pidana Pemilihan Umum Yang Bernilai Keadilan, Publising, Semarang

[2] C.S.T. Kansil and Christine S.T. Kansil, 2004, Pokok-pokok Hukum Pidana, Jakarta, Pradnya Paramita

[3] Dedi Mul yadi, 2012, Kebijakan Legislasi Tentang Sanksi Pidana Pemilu Legislatif di Indonesia Dalam Perspekrif Demokrasi, Gramata Publising

[4] Dosminikus Rato, 2010, Filasafat Hukum Mencari dan Memahami Hukum, PT Presindo, Yogyakarta

[5] Jimly Asshiddiqie, 2005, Konstitusi dan Konstitusionalisme Indonesia, Penerbit Konstitusi Press, Jakarta

[6] S.R. Sianturi, 2002, Asas-asas Hukum Pidana di Indonesia dan Penerapannya, Ed.3, Jakarta: Storia Grafika

[7] Topo Santoso, 2006, Tindak Pidana Pemilu, Sinar Grafika, Jakarta

\section{Regulations:}

[1] Constitution of the Republic of Indonesia 1945

[2] Criminal Code

[3] Act No. 15 of 2011 concerning Election Administrators

[4] Act No. 7 of 2017 concerning Elections 